\title{
REW Application Possibilities for the Production of Combined Metal - Plastic Joints
}

Pavol Sejč (0000-0001-5298-4978), Branislav Vanko (0000-0003-2332-4991), Zuzana Gábrišová (0000-0003-36831220)

Faculty of Mechanical Engineering, Slovak University of Technology in Bratislava, Námestie slobody 17, 81231 Bratislava 1, Slovak Republic. E-mail: pavol.sejc@stuba.sk

In this paper, innovative resistance element welding (REW) technology for joining galvanized steel sheets to thermoplastics (PMMA) is introduced. The essence of the innovation is in the use of a special bimetallic joining element consisting of the core made of a $\mathrm{Sn} 60 \mathrm{~Pb}$ solder, and the sleeve made of a $\mathrm{Cu}$ tube. During resistance heating, the solder melts, thus allowing the formation of a metallurgical joint with galvanized steel sheet. Since Sn60Pb solder melting occurs at temperatures (from 183 to $190{ }^{\circ} \mathrm{C}$ ) below the thermal decomposition temperature of most thermoplastics (for PMMA above $300{ }^{\circ} \mathrm{C}$ ), there is no thermal destruction of the PMMA material around the joint. The mechanical fixation of the thermoplastic material at the overlap joint is provided by the sleeve made of $\mathrm{Cu}$ tube which has a substantially higher strength than a $\mathrm{Sn} 60 \mathrm{~Pb}$ solder.

Keywords: Resistance Element Welding, Soldering, Metal-to-Plastic Joining, Bimetallic Joining Element

\section{Introduction}

At present, when joining thin sheets made of different metal materials, fusion welding technologies like resistance element welding (REW) or resistance spot welding (RSW) are usually used, but solid-state joining processes can also be applied $[1,2,3]$. The REW technology is used especially in the production of overlap joints on car bodies where it is applied to join, for example, steel stampings with an aluminum alloy $[4,5,6,7]$. These are specific joints of materials with significantly different melting temperatures, where standard fusion welding processes cannot be applied. The principle of the original REW technology comprises the use of a joining element (rivet, fastener) with a cylindrical shaft and a head, by means of which an overlap joint of the perforated upper sheet with the lower sheet is created by resistance heating (Fig. 1). The hole in the upper material defines the connecting point and partially fixes the joining element before welding. Resistance heating is used to create the welded joint. For applying REW technologies, a resistance welding gun primarily intended for spot welding is used. This involves the formation of a fusion joint between the lower material and the joining element in combination with a creation of a positive fit and force fit between the joining element and the upper material (Fig. 2).
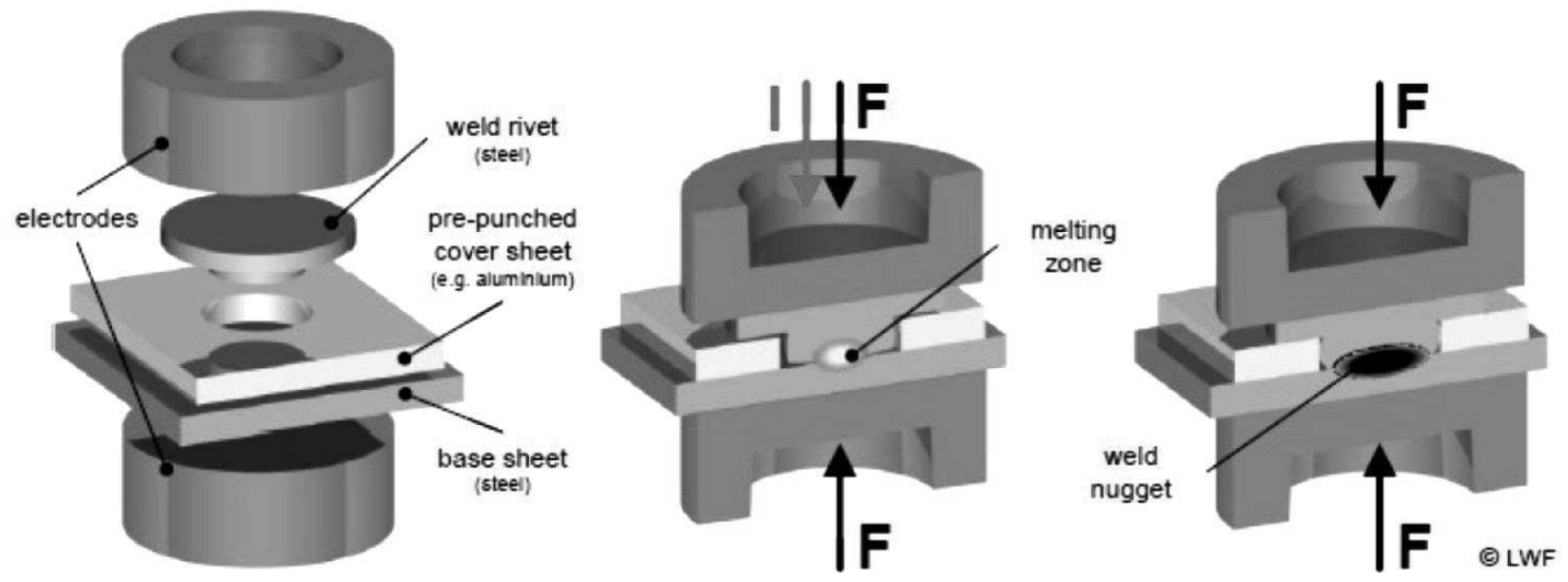

Fig. 1 The principle of welding by REW technology [7]

In general, this method has been developed to join steel sheets with aluminum alloy sheets using a steel joining element. In this case, a welded joint is formed between the steel sheet and the joining element. The 
main process parameters of the REW are:

- welding time,

- welding current,

- clamping force.

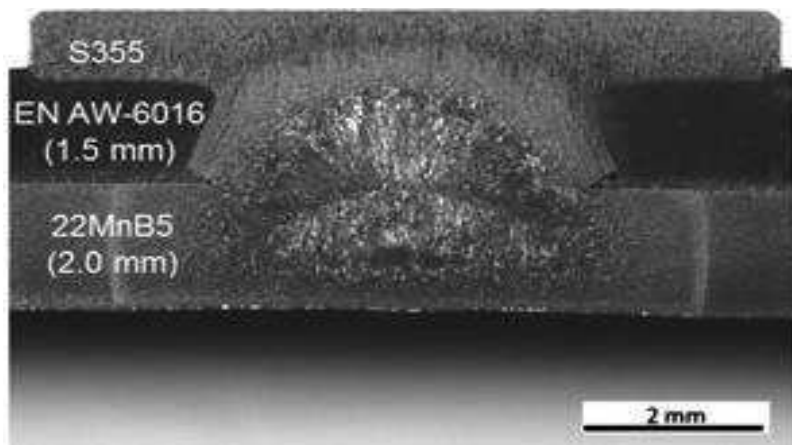

Fig. 2 The cross section of the REW joint of the $22 \mathrm{MnB} 5$ steel sheet with the 6016 aluminum alloy sheet [6]

Welding time is defined as the time during which the welding current flows through the welded materials. Welding time must be long enough to cause the joining element to melt, but, at the same time, as short as possible to avoid over-heating of the weld area. The clamping force significantly influences the thermal phenomena during welding by affecting the transition resistance between the materials and ensuring that the welded materials are assembled and remain in contact. Unlike conventional RSW, the clamping force also ensures the deformation of the joining element in the axial direction. If the clamping force is sufficiently high, a tight force fit is formed between the joining element and the upper sheet due to deformation.

From the Joule-Lenz law $[1,8]$ :

$$
Q=R \cdot I^{2} . t[D],
$$

where

Q...heat [],

$R$...electric resistance $[\Omega]$,

I...electric current $[\mathrm{A}]$,

$t$...current flow time $[\mathrm{s}]$,

It is clear that the heat generated in the weld is directly proportional to the square of the welding current. In terms of thermal phenomena, the current density indicating the amount of welding current per unit area is also important. In this respect, the electrode contact surface with welded material is of great importance. Compared to RSW, the contact surface in REW not only depends on the geometric parameters of the electrodes but also on the geometry of the joining element.

An alternative solution is to use a joining element made of a material suitable for brazing/soldering the lower material (steel sheet). Thus, the joint between the joining element and the steel sheet does not occur by fusion welding but by brazing/soldering. When joining, the steel sheet is only heated to a brazing/soldering temperature. This is much lower than a fusion welding temperature. Lower heat input reduces heatinduced stresses and deformations that occur during heating and cooling. For joining steels or non-ferrous metals (aluminum, copper) the most suitable materials for brazing are those with a melting point above 450 ${ }^{\circ} \mathrm{C}$. Such materials typically possess adequate properties to provide the required strength of the force fit between the joining element and the upper material. However, if a material with a very low melting or decomposition temperature (e.g. thermoplastic) is joined to the lower metal sheet, unwanted destruction of the upper material may occur when joining at temperatures above $450{ }^{\circ} \mathrm{C}$. Thermal decomposition and oxidation of the upper material at a location near the joint can significantly affect the overall joint strength.

In this case, it seems to be a better to use a material primarily intended for soldering (e.g. tin-based solder) to produce the joining element. Solders have a melting point of less than $450^{\circ} \mathrm{C}$ but have a significantly lower strength than the braze [9]. Thus, the use of solder materials to produce a joining element for REW technology will not fulfill the condition to produce the desired tight force fit with the upper plastic material.

The aim of the work was to design and verify the suitability of new bimetallic joining elements (fasteners) and to optimize the REW heating parameters for metal-to-plastic joining.

\section{Experiment}

Our design is based on the requirement to join steel with a low melting point material (thermoplastic). Since the high temperature at the joint can cause thermoplastic destruction, we have proposed an innovative REW technology for joining metal-to-plastic materials, using a bimetallic joining element to replace the steel fastener. Bimetallic joining element works at lower temperatures and has been designed as a element consisting of a hard sleeve and a soft core. The core is made of a $\mathrm{Sn} 60 \mathrm{~Pb}$ solder, which is suitable for soldering of galvanized steel sheets, which in our case was the first initial condition. The solder is melted at a low temperature from 183 to $190{ }^{\circ} \mathrm{C}$. The melting point of the solder is lower than the thermal decomposition temperature of most thermoplastics (for PMMA, depolymerization takes place at the temperature above $300{ }^{\circ} \mathrm{C}[10]$ ), thus the second initial condition was fulfilled. The solder enables the creation of a permanent joint with galvanized steel sheet. However, since the solder material has low strength (Tab. 1) to provide a force fit joint, the tight force fit with the thermoplastic upper material (PMMA) is provided by a sleeve made of a $\mathrm{Cu}$ tube. The mechanical properties of the $\mathrm{Cu}$ tube material (Electrolytic Tough Pitch Copper) are given in Tab. 1. The shape and dimensions of the bimetallic joining element are shown in Fig. 3. 
Tab. 1 Basic properties of $\mathrm{Cu}$ and $\mathrm{Sn60Pb}[11,12]$

\begin{tabular}{|l|l|l|l|l|}
\hline Material & $\begin{array}{l}\text { Yield Strength } \\
\text { YS }\left(\mathrm{R}_{\mathrm{p} 0,2)}[\mathrm{MPa}]\right.\end{array}$ & $\begin{array}{l}\text { Ultimate Tensile Strength } \\
\text { UTS }[\mathrm{MPa}]\end{array}$ & $\begin{array}{l}\text { Elongation to Fracture } \\
\mathrm{A}[\%]\end{array}$ & $\begin{array}{l}\text { Melting Temperature } \\
\mathrm{T}_{\mathrm{M}}\left[{ }^{\circ} \mathrm{C}\right]\end{array}$ \\
\hline $\mathrm{Cu}$ & $60 \div 220$ & $200 \div 300$ & $4 \div 30$ & 1083 \\
\hline $\mathrm{Sn} 60 \mathrm{~Pb}$ & - & $40 \div 80$ & 40 & $183 \div 190$ \\
\hline
\end{tabular}

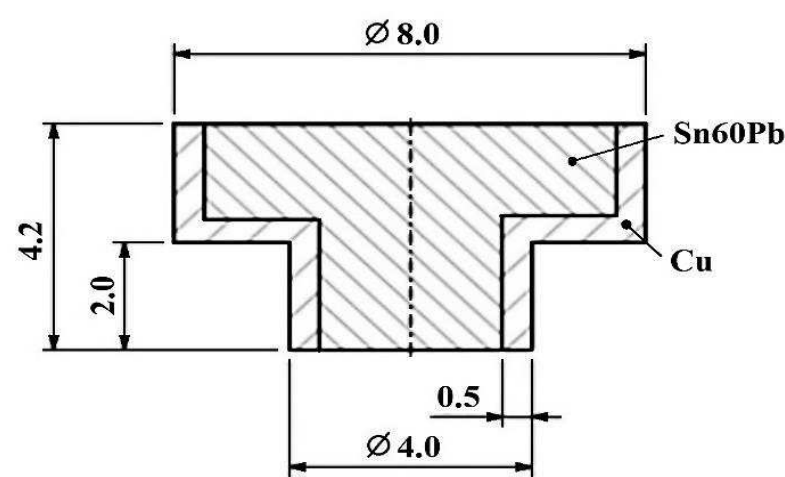

Fig. 3 Shape and dimensions of bimetallic joining element
To produce overlap joints, both side galvanized bake-hardening steel HX220BD with a sheet thickness of $0.8 \mathrm{~mm}$ and the $100 \mathrm{MBO}$ type zinc coating was used. The $100 \mathrm{MBO}$ type zinc coating means that the minimum weight of surface coating from both sides is 100 g. $\mathrm{m}^{-2}$ (this corresponds to approximately $15 \mu \mathrm{m}$ thickness of $\mathrm{Zn}$ ), and that the surface coating is with minimized spangle (M), improved (B) and oiled (O) [13]. The basic mechanical properties and chemical composition of the steel are given in Tab. 2 and Tab. 3.

Tab. 2 Chemical composition of HX220BD 100MBO steel [13]

\begin{tabular}{|l|l|l|l|l|l|l|}
\hline $\mathrm{C}[\%]$ & $\mathrm{Ti}[\%]$ & $\mathrm{Si}[\%]$ & $\mathrm{Mn}[\%]$ & $\mathrm{P}[\%]$ & $\mathrm{S}[\%]$ & $\mathrm{Nb}[\%]$ \\
\hline 0.1 & 0.12 & 0.5 & 0.7 & 0.01 & 0.03 & 0.09 \\
\hline
\end{tabular}

Tab. 3 Basic mechanical properties of HX220BD 100MBO steel [13]

\begin{tabular}{|l|l|l|}
\hline $\begin{array}{l}\text { Yield Strength } \\
\mathrm{YS}\left(\mathrm{R}_{\mathrm{p} 0,2)}[\mathrm{MPa}]\right.\end{array}$ & $\begin{array}{l}\text { Ultimate Tensile Strength } \\
\text { UTS }[\mathrm{MPa}]\end{array}$ & $\begin{array}{l}\text { Elongation to Fracture } \\
\text { A }[\%]\end{array}$ \\
\hline $220 \div 280$ & $320 \div 400$ & 32 \\
\hline
\end{tabular}

The steel sheet was joined to the QUINN XT PMMA (Polymethyl Methacrylate) thermoplastic, which was colorless and $2 \mathrm{~mm}$ thick. It is primarily intended for deep hot drawing, polishing, gluing, as well as a construction element used for manufacturing safety covers and parts for the instruments. The basic properties of this thermoplastic material are shown in Tab. 4.

Tab. 4 Basic properties of QUINN XT PMMA [14]

\begin{tabular}{|l|l|l|}
\hline $\begin{array}{l}\text { Ultimate Tensile Strength } \\
\text { UTS }[\mathrm{MPa}]\end{array}$ & $\begin{array}{l}\text { Elongation to Fracture } \\
\mathrm{A}[\%]\end{array}$ & $\begin{array}{l}\text { Decomposition Temperature } \\
\mathrm{T}_{\mathrm{D}}\left[{ }^{\circ} \mathrm{C}\right]\end{array}$ \\
\hline 70 & 4 & 280 \\
\hline
\end{tabular}

The position of the materials before joining is shown in Fig. 4 and Fig. 5. After cutting the material to a required size, a hole $(\varnothing \mathrm{d}=4.1 \mathrm{~mm})$ with a recess ( $\varnothing \mathrm{D}=8.1 \mathrm{~mm}, \mathrm{~h}=1 \mathrm{~mm}$ ) was drilled into the thermoplastic to insert the joining element. Before joining, galvanized steel sheets were cleaned of grease and dirt with acetone. Subsequently, SF-601 liquid flux, which is intended for soldering with tin solders [15], was applied to the surface of the steel sheet at the connection point.

The ARO type XMA $26 \mathrm{kVA}$ resistance welding gun with ULB 1.4 universal VTS control system was used for heating of materials at the joint. The parameters were set as follows: welding current $\mathrm{I}=3.5 \mathrm{kA}$, clamping force $\mathrm{F}=735 \mathrm{~N}$, and welding time $\mathrm{t}=5,10$, 15 cycles (Tab. 5). For a $50 \mathrm{~Hz}$ power supply, one cycle last 20 milliseconds. By changing the welding time, the heat input to the joint was regulated. The real values of the selected process parameters were measured by using the Miyachi measuring device of the Weld Checker MM-356 B type. The set and measured process variables of current, voltage, resistance heating time and heat input are given in Tab. 5.
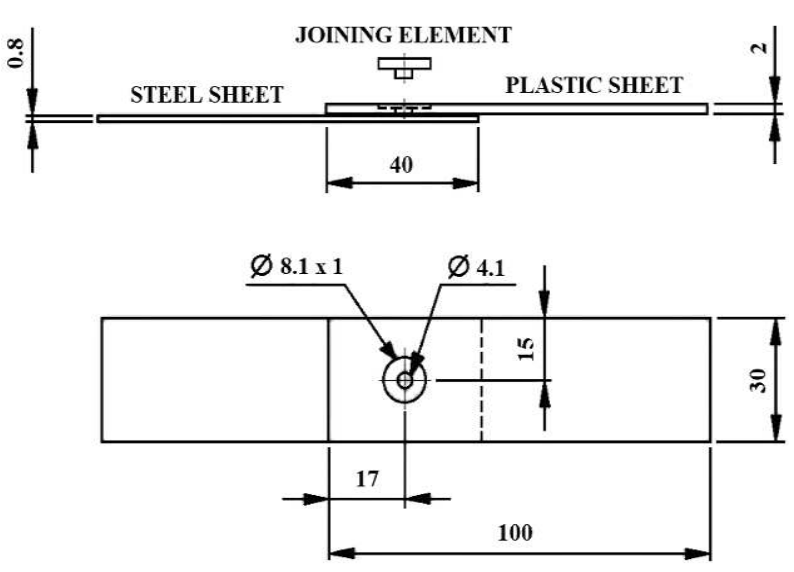

Fig. 4 Dimensions and position of joined materials 


\section{$-\mathrm{Cu}-5 \mathrm{n} 60 \mathrm{~Pb}$}

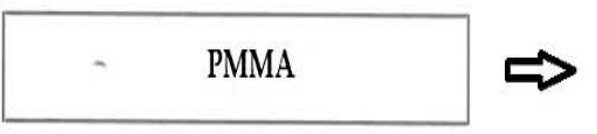

\section{HX220BD 100MBO}

Fig. 5 Assembling of joined materials

Tab. 5 Set and measured parameters

\begin{tabular}{|l|l|l|l|l|l|l|}
\hline \multirow{2}{*}{ Sample No. } & \multicolumn{4}{l}{ Set parameters } & \multicolumn{3}{l|}{ Measured/Calculated parameters } \\
\cline { 2 - 7 } & $\mathrm{I}[\mathrm{kA}]$ & $\mathrm{F}[\mathrm{N}]$ & $\mathrm{t}[$ cycles $(\mathrm{ms})]$ & $\mathrm{I}_{\mathrm{R}}[\mathrm{kA}]$ & $\mathrm{U}[\mathrm{V}]$ & $\mathrm{Q}[\mathrm{k}]$ \\
\hline 1. & 3.5 & 735 & $15(300)$ & 3.49 & 0.46 & 0.48 \\
\hline 2. & 3.5 & 735 & $15(300)$ & 3.43 & 0.45 & 0.46 \\
\hline 3. & 3.5 & 735 & $15(300)$ & 3.38 & 0.45 & 0.46 \\
\hline 4. & 3.5 & 735 & $15(300)$ & 3.39 & 0.45 & 0.46 \\
\hline 5. & 3.5 & 735 & $15(300)$ & 3.40 & 0.44 & 0.45 \\
\hline 6. & 3.5 & 735 & $10(200)$ & 3.39 & 0.46 & 0.31 \\
\hline 7. & 3.5 & 735 & $10(200)$ & 3.38 & 0.43 & 0.29 \\
\hline 8. & 3.5 & 735 & $10(200)$ & 3.44 & 0.47 & 0.32 \\
\hline 9. & 3.5 & 735 & $10(200)$ & 3.35 & 0.47 & 0.31 \\
\hline 10. & 3.5 & 735 & $10(200)$ & 3.41 & 0.44 & 0.30 \\
\hline 11. & 3.5 & 735 & $5(100)$ & 3.36 & 0.48 & 0.16 \\
\hline 12. & 3.5 & 735 & $5(100)$ & 3.38 & 0.47 & 0.16 \\
\hline 13. & 3.5 & 735 & $5(100)$ & 3.40 & 0.45 & 0.15 \\
\hline 14. & 3.5 & 735 & $5(100)$ & 3.40 & 0.46 & 0.16 \\
\hline 15. & 3.5 & 735 & $5(100)$ & 3.35 & 0.48 & 0.16 \\
\hline
\end{tabular}

The type II (CuCrZr) electrodes designed for RSW of galvanized steel sheets were used. On the PMMA side, an electrode with a planar contact surface (FC geometry type) was used. On the galvanized steel sheet side, an electrode with a rounded surface (FB geometry type) was used. In addition to the electrical current supply, the planar surface of the electrode had the task of positioning the joining element in such a way that its axis was perpendicular to the surface of the steel sheet.

The following parameters were evaluated on the samples:

- quality of the joints and the occurrence of defects by visual inspection,

- mechanical properties of joints by tensile test,

- joint structures and internal defects by metallographic examination.

Conventional metallographic techniques were used to produce cross-sections of the joints. The joints were cut and embedded in Dentacryl (methyl methacrylate) and then ground and polished.

\section{Results and discussions}

The Fig. 6a shows the joint using a soldering (heating) time $\mathrm{t}=15$ cycles (heat input $\mathrm{Q}=0.46 \mathrm{~kJ}$ ). The top of the joint (PMMA side) shows the solder spatter out of the joining element. The spatter was observed both at the connection point (galvanized steel sheet PMMA interface) and at the head of the joining element. The cause of the spatter was the high pressure of the molten solder, which was created during rapid resistance heating by dilating the core material of the joining element. At a heating time $\mathrm{t}=10$ cycles $(\mathrm{Q}=$ $0.31 \mathrm{~kJ}$ ), the molten solder spurted out again, but the total volume of the spattered metal was reduced (Fig. 6b). In terms of metal spattering of the joining element core during resistance heating, the best results were obtained using a heating time $\mathrm{t}=5$ cycles (Fig. 6c) when the lowest Joule heat $(\mathrm{Q}=0.16 \mathrm{~kJ})$ was used for the joining. As demonstrated in this case, the molten solder has been spattered neither between the materials to be joined, nor on the top of the head of the joining element.

On the underside of the galvanized steel sheet (Fig. 7) we can notice that even in the case of maximum 
not melt, which is very convenient in terms of maintaining the corrosion resistance of the steel sheet.
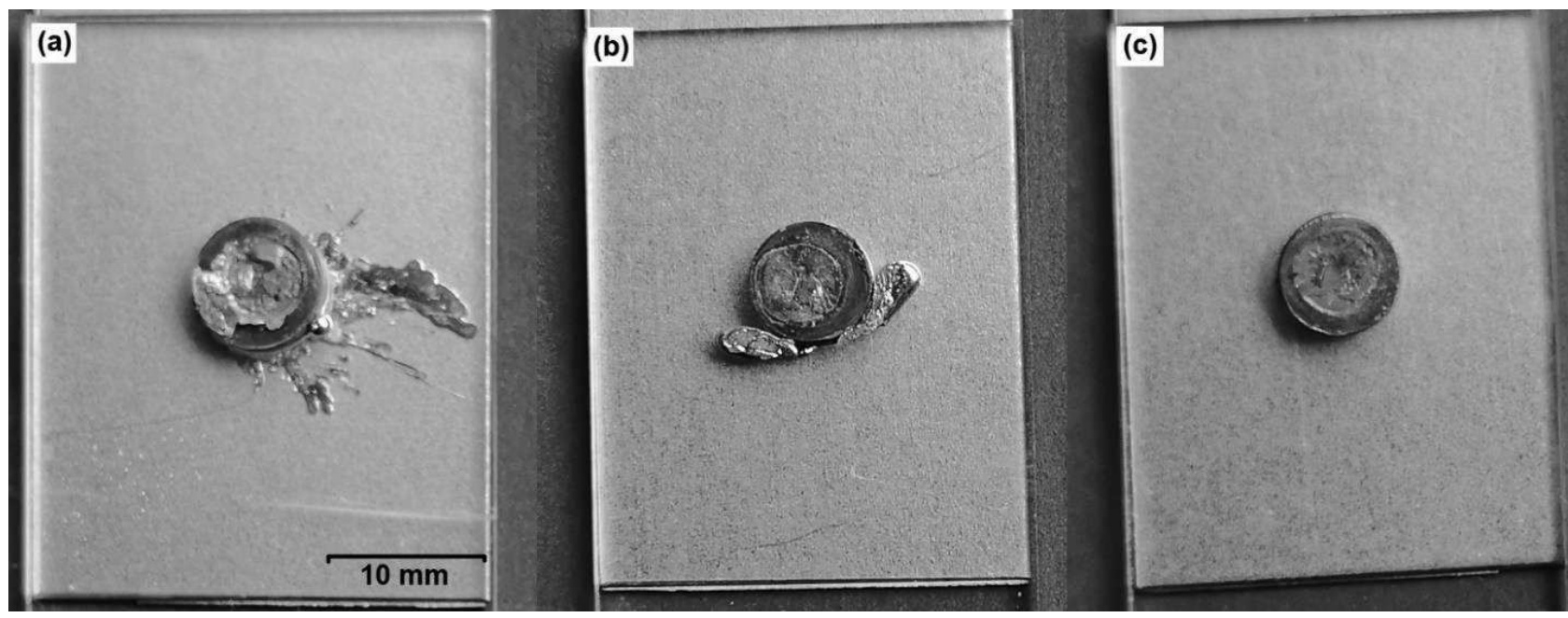

Fig. 6 Appearance of joints produced in different heating time: a) $t=15$ gycles (sample no. 3), b) $t=10$ ycles (sample no. 9), c) $t=5$ cycles (sample no. 11)

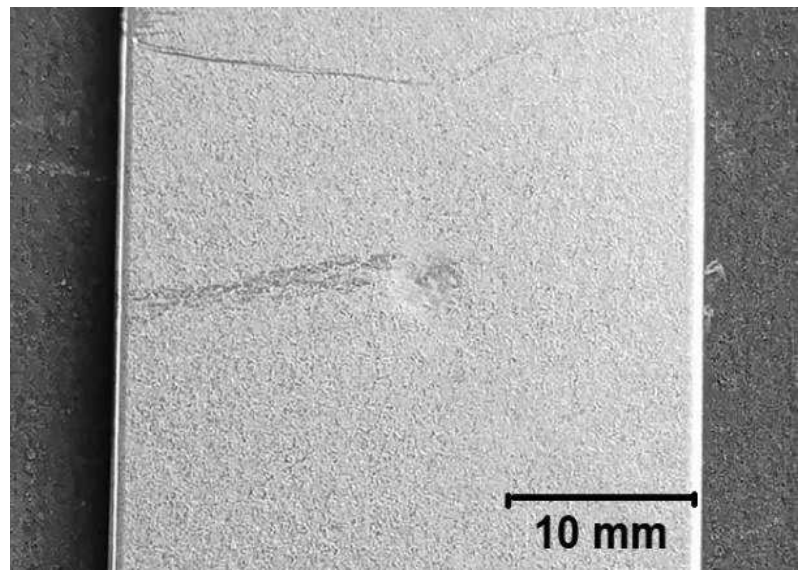

Fig. 7 Bottom view on the galvanized steel sheet of the sample no. $3(t=15$ cycles $)$

As observed in the cross-sections of the joints made at various joining parameters (Fig. 8), there are some defects in the joining elements, such as strip and voids, created in the production of the joining elements. The defects were caused by casting the $\mathrm{Sn} 60 \mathrm{~Pb}$ solder into the $\mathrm{Cu}$ tube and the subsequent forming.

It can also be noted that, with the increasing soldering time, the amount of heat applied and subsequently, the volume of the molten solder, which almost reaches the top surface of the joining element, increases. This can lead to forming solder spatter, which is inconvenient due to the possibility of cavity formation. On both the sides, the joining element is in contact with the PMMA and presses it to the joint. No defects (such as cracks, non-wetted surface, voids, etc.) were identified at the joint between the joining element and the galvanized steel sheet.
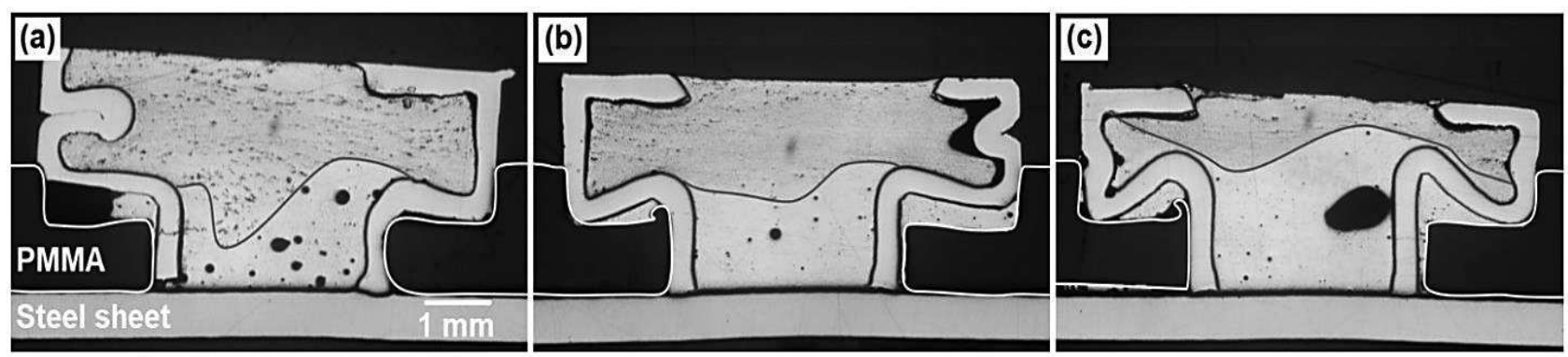

Fig. 8 Cross-sections of the joints produced in different heating times: a) $t=5$ cycles, b) $t=10 \mathrm{cycles}, c) t=15 \mathrm{cycles}$

Some of the solder even leaked under the $\mathrm{Cu}$ tube (Fig. 9), increasing the contact area and hence the strength of the soldered joint. In Fig. 9 and Fig. 10, it can be noted that the solder fully wetted the galvanized steel sheet and the joining element sleeve, which implies that the selected Sn60Pb solder was chosen appropriately for this purpose.
It has been prepared 3 series of samples for the tensile test. Different soldering time was used for each series ( $t=5,10,15$ cycles), while the other parameters remained unchanged. The tensile test was performed using the Instron 1195 universal testing machine. The results of tensile test of overlap joints are shown in Tab. 6. 


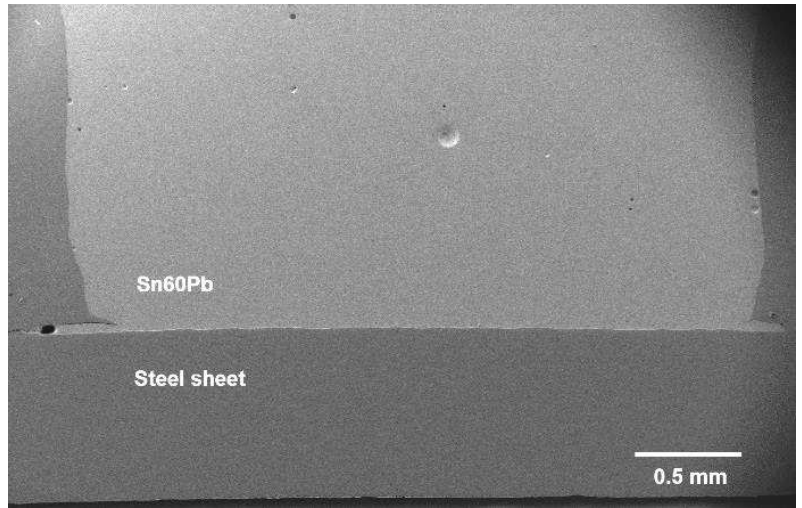

Fig. 9 Cross-section of the sample no.9

The average values of the joint strength (evaluated by the average values of the maximum tensile force) ranged from $172 \mathrm{~N}$ (at a heating time $\mathrm{t}=15$ cycles) to

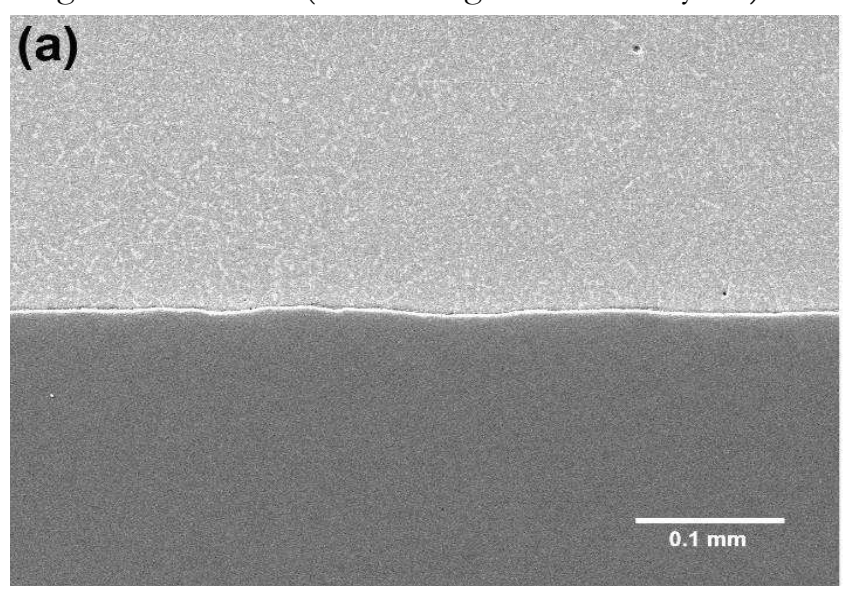

$316 \mathrm{~N}$ (at a heating time $\mathrm{t}=10$ cycles). The results showed that the heat input will also have a significant effect on the mechanical properties of the REW joint between galvanized steel sheet and PMMA made by a bimetallic joining element. The minimum average strength value achieved at maximum heat input is very likely due to the spattering of the metal of the core of the bimetallic joining element during heating (Fig. 6).

As shown in Fig. 11, in the tensile test the joint samples were broken at the soldered joint between the bimetallic joining element and the galvanized steel sheet. It can further be noted that the heat input did not cause any changes in the PMMA or in the zone around the soldered joint. This observation met the basic condition when designing the mode of joining galvanized steel sheet with thermoplastic.

Fig. 10 Solder-steel sheet interface of the sample no. 9: a) overview, b) detail

Tab. 6 Tensile test results

\begin{tabular}{|c|c|c|c|}
\hline $\begin{array}{l}\text { Sample } \\
\text { No. }\end{array}$ & $\begin{array}{l}\text { Heating Time } \\
\mathrm{t} \text { [cycles (ms)] }\end{array}$ & $\begin{array}{l}\text { Heat Input } \\
\mathrm{Q}[\mathrm{kJ}]\end{array}$ & $\begin{array}{l}\text { Maximum Tensile Force } \\
F_{\max }[\mathrm{N}]\end{array}$ \\
\hline 1. & $15(300)$ & 0.48 & 350 \\
\hline 2. & $15(300)$ & 0.46 & 325 \\
\hline 3. & $15(300)$ & 0.46 & 125 \\
\hline 4. & $15(300)$ & 0.46 & $90^{*}$ \\
\hline 5. & $15(300)$ & 0.45 & 355 \\
\hline Average value & $15(300)$ & 0.46 & 289 \\
\hline 6. & $10(200)$ & 0.31 & 200 \\
\hline 7. & $10(200)$ & 0.29 & 365 \\
\hline 8. & $10(200)$ & 0.32 & $-* *$ \\
\hline 9. & $10(200)$ & 0.31 & 357 \\
\hline 10. & $10(200)$ & 0.30 & 370 \\
\hline Average value & $10(200)$ & 0.31 & 316 \\
\hline 11. & $5(100)$ & 0.16 & 215 \\
\hline 12. & $5(100)$ & 0.16 & 160 \\
\hline 13. & $5(100)$ & 0.15 & 135 \\
\hline 14. & $5(100)$ & 0.16 & 130 \\
\hline 15. & $5(100)$ & 0.16 & 220 \\
\hline Average value & $5(100)$ & 0.16 & 172 \\
\hline
\end{tabular}




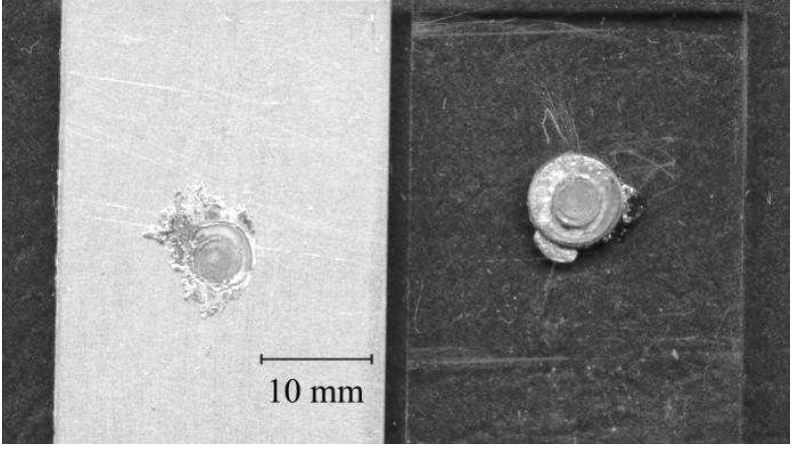

Fig. 11 Sample no. $2(t=15$ cycles) after the tensile test

An overall view on the fracture surface from the side of the galvanized steel sheet is shown in Fig. 12. Details of the selected areas of the failure of the joint in the central part and at its edge are shown in Fig. 13.

The appearance of the fracture surface demonstrates very good wetting of the galvanized steel sheet with the Sn $60 \mathrm{~Pb}$ solder. The non-wetted areas by the

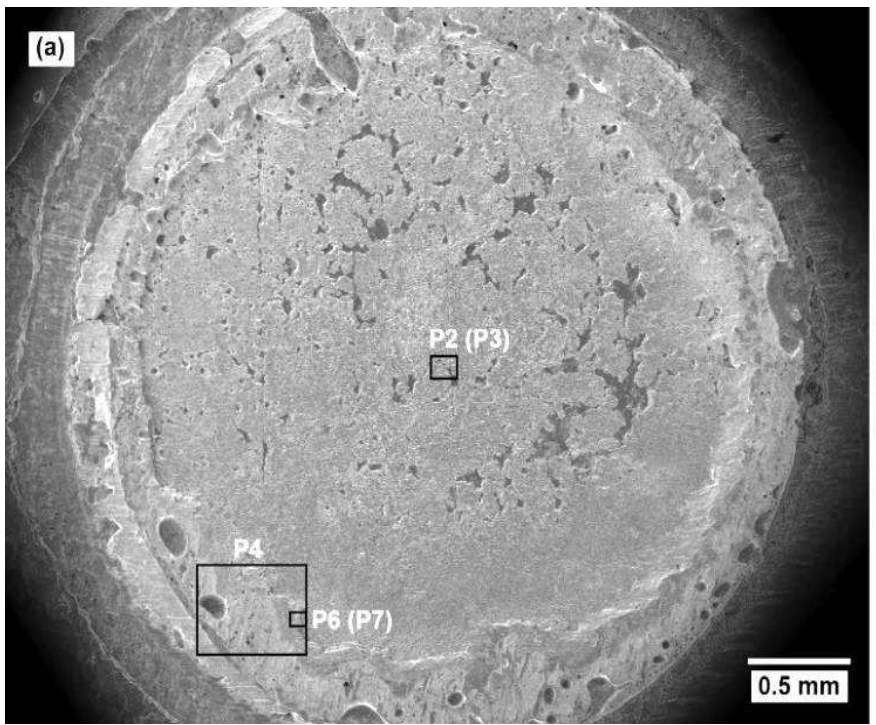

solder represent less than $10 \%$ of the total cross-sectional area of the joining element. The locations of the voids due to insufficient soldering filler metal on the fracture surface are well documented by the higher $\mathrm{Zn}$ content (Fig. 12b) from the steel sheet coating. The occurrence of solder base elements $(\mathrm{Sn}$ and $\mathrm{Pb}$ ) is relatively sharply bounded on the fracture surface (Fig. 12b), which confirms the presence of a sufficient clamping force during resistance heating to minimize the spatter of molten solder from the joining element. In Fig. 13a, we can see the character of the fracture surface in its central area with the local occurrence of non-wetted surface. The detail in Fig. 13b confirms that the integrity has been violated here by a characteristic dimpled ductile fracture. Fig. 13c shows the detail of the edge area of the fracture surface of the joint with the occurrence of gas porosity and insufficient soldering filler metal voids. A detail of the topography of the exposed porosity in this area is shown in Fig. 14a. Moreover, EDX analysis (Fig. 14b) showed the occurrence of oxide inclusions on the edge areas of the joint.
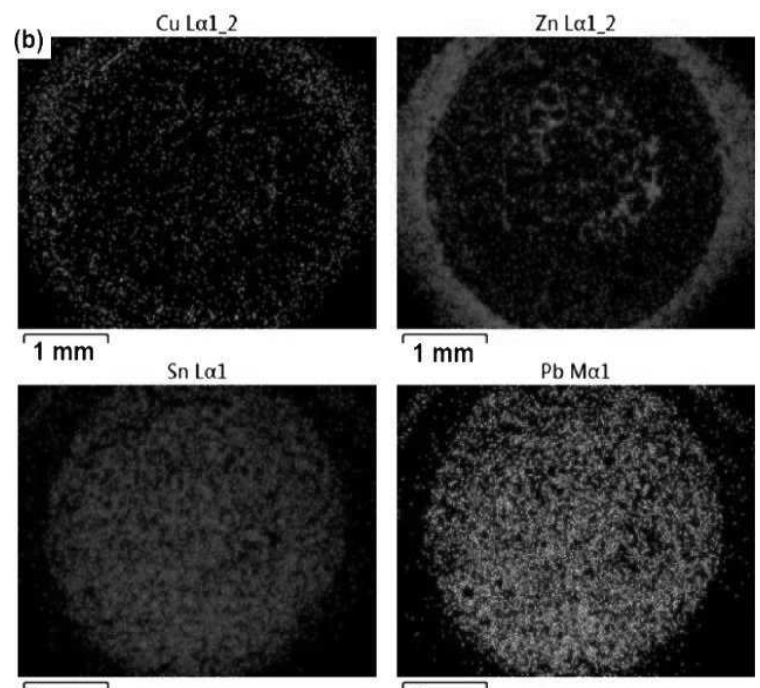

$1 \mathrm{~mm}$

$1 \mathrm{~mm}$

Fig. 12 Sample no. 9: a) overall view on the fracture surface from the side of galvanized steel sheet, b) distribution maps of selected elements

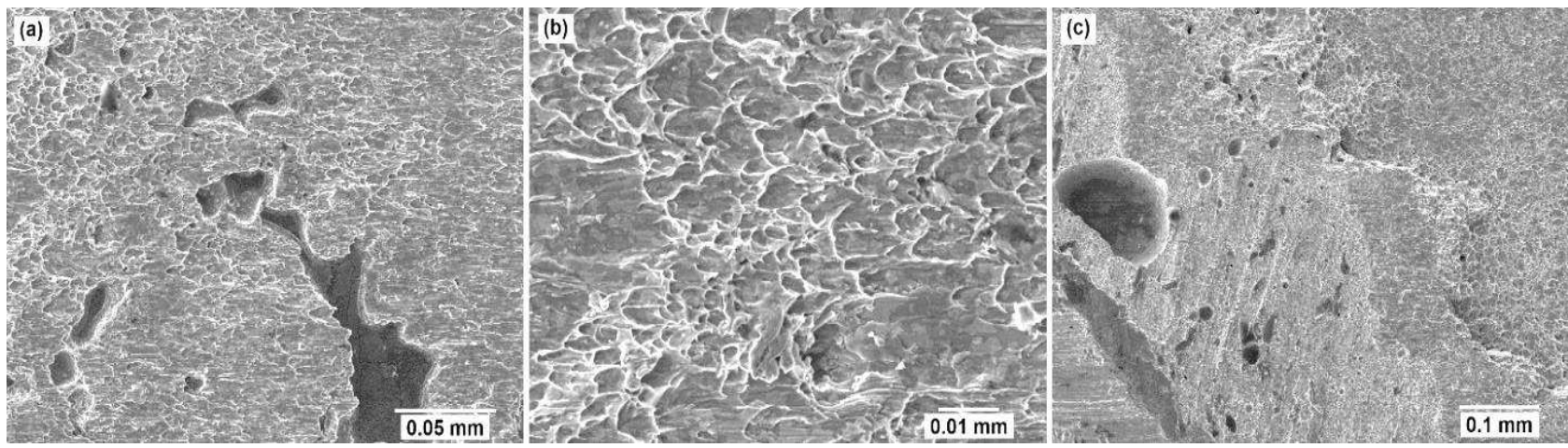

Fig. 13 Appearance of selected areas of fracture surface of the sample no. 9 (see positions in Fig. 12): a) position P2 - overall view in central area, b) position P3 - detailed view in central area, c) position P4 - overall view in edge area 

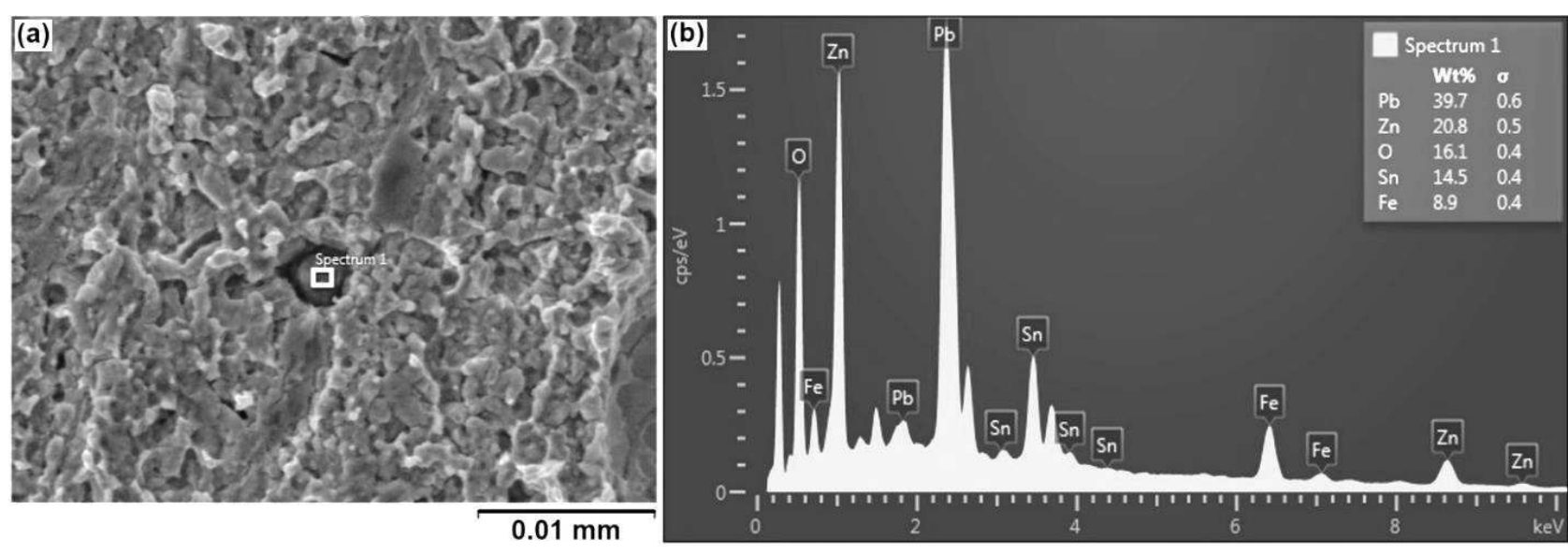

Fig. 14 Detail of the edge area of the fracture surface of the sample no. 9: a) position P7 (see Fig. 12), b) spectral analysis of globular inclusion

\section{Results}

The aim of the work was to verify the possibility of using the REW (Resistance Element Welding) technology for joining of galvanized steel sheets with thermoplastics. A bimetallic joining element was designed, where the core was made of a $\mathrm{Sn} 60 \mathrm{~Pb}$ solder and the sleeve of a $\mathrm{Cu}$ tube. This solution allowed the creation of a soldered joint between the joining element and the galvanized steel sheet at a temperature below the decomposition temperature of the thermoplastic (PMMA) used, and a force fit between the joining element and the thermoplastic.

Based on the results obtained, the following conclusions can be drawn:

- resistance heating parameters $\mathrm{I}=3.5 \mathrm{kA}, \mathrm{F}=$ $735 \mathrm{~N}$, and $\mathrm{t}=15,10,5$ cycles meet the requirements for creating a soldered joint between the bimetallic joining element and the galvanized steel sheet without thermal destruction of the upper joined material made of thermoplastic (PMMA),

- the amount of heat regulated by the change of the heating time influenced the volume of the molten solder material in the core of the bimetallic joining element, as well as the melt spatter and the presence of cavities in the solder,

- the defects (spatter, voids) affected the joint strength, which was proved by the tensile test,

- the best results were obtained at a heating time of $t=10$ cycles, where the strength of the joint evaluated by the average tensile force achieved $\mathrm{F}_{\max }=316 \mathrm{~N}$,

- the joint was broken by a dimpled ductile fracture in the soldered joint,
- the analysis of the cross-sections and fracture surfaces showed good wetting of galvanized steel sheet by a solder with a minimum occurrence of non-wetted areas (less than $10 \%$ ),

- the low heating temperature ensured the preservation of the $\mathrm{Zn}$ protective layer on the steel sheet on the edges of the soldered joint.

\section{Acknowledgement}

\section{The results given in this paper were obtained as a part of VEGA 1/0394/19 research project.}

\section{References}

[1] ZHANG, H., SENKARA, J. (2011). Resistance welding: fundamentals and applications, second edition. CRC Press. ISBN-13: 978-1-43985-371-9.

[2] MARTINSEN, K., HU, S. J., CARLSON, B. E. (2015). Joining of dissimilar materials. In: CIRP Annals - Manufacturing Technology, 64, iss. 2, pp. 679 699. https://doi.org/10.1016/j.cirp.2015.05.006.

[3] HABIBIZADEH, A., HONARPISHEH, M., GOLABI, S. (2021). Determining Optimum Shear Strength of Friction Stir Spot Welding Parameters of AA1050/C10100 Joints. In: Manufacturing Technology, 21, no. 3, pp. 315 - 329. https://doi.org/10.21062/mft.2021.046.

[4] MESCHUT, G., JANZEN, V., OLFERMANN, T. (2014). Innovative and highly productive joining technologies for multi-material lightweight car body structures. In: Journal of Materials Engineering and Performance, 23, pp. $1515 \quad-\quad 1523$. https://doi.org/10.1007/s11665-014-0962-3.

[5] CHASTEL, Y., PASSEMARD, L. (2014). Joining technologies for future automobile multi- 
material modules. In: Procedia Engineering, 81, pp. 2104 - 2110. https://doi.org/10.1016/j.proeng.2014.10.293.

[6] MESCHUT, G., HAHN, O., JANZEN, V., OLFERMANN, T. (2014). Innovative joining technologies for multi-material structures. In: Welding in the World, 58, pp. 65 - 75. https://doi.org/10.1007/s40194-013-0098-3.

[7] MESCHUT, G., SCHMAL, CH., OLFERMANN, T. (2017). Process characteristics and load-bearing capacities of joints welded with elements for the application in multi-material design. In: Welding in the World, 61, $\quad$ pp. $435 \quad$ - 442. https://doi.org/10.1007/s40194-017-0431-3.

[8] SEJČ, P., BELANOVÁ, J., GÁBRIŠOVÁ, Z., VANKO, B. (2020). The Influence of Parameters of the Resistance Projection Welding of M10 Steel Nuts to the Galvanized Steel Sheet DP 600 on Selected Joint Characteristics. In: Manufacturing Technology, 20, no. 6, pp. 822 - 833. https://doi.org/10.21062/mft.2020.090.

[9] Brazing handbook, fifth edition. (2011). American Welding Society, ASM International. ISBN-13: 978-0-87171-046-8.

[10] KOROBEINICHEVA, O. P., PALETSKYA, A. A., GONCHIKZHAPOVA, M. B., GLAZNEVA, R. K., GERASIMOVA, I. E.,
NAGANOVSKY, Y. K., SHUNDRINAD, I. K., SNEGIREVE, A. Yu., VINUF, R. (2019). Kinetics of thermal decomposition of PMMA at different heating rates and in a wide temperature range. In: Thermochimica Acta, 671, pp. 17 https://doi.org/10.1016/j.tca.2018.10.019.

[11] VIANCO, P. T. (1999). Soldering handbook, third edition. American Welding Society. ISBN-13: 978-0-87171-618-7.

[12] ASM Specialty handbook: copper and copper alloys. (2001). Edited by J.R. Davis, Davis \& Associates. ASM International. ISBN-13: 978-087170-726-8.

[13] U. S. Steel Košice. Bake-hardening steels. https://www.usske.sk/en/products/hot-dip-galvanized/bake-hardening-steels, (accessed 12.4.2021).

[14] Quinn Plastics. Product Information: QUINN XT. http://vascony.com/wp-content/uploads/2014/01/en-quinn-xt-10-07.pdf, (accessed 12.4.2021).

[15] VUZ. Spájky a tavivá na spájkovanie. https://www.vuz.sk/uploads/wysiwyg/katalógy/08_Spajky_ataviva_na_spajkovanie.pdf, (accessed 12.4.2021), Slovak. 